\title{
A Handbook of Greek Vase Painting. By Mary A. B. Herford
}

\section{David M. Robinson}

To cite this article: David M. Robinson (1920) A Handbook of Greek Vase Painting. By Mary A.

B. Herford, The Art Bulletin, 2:3, 178-181, DOI: 10.1080/00043079.1920.11409675

To link to this article: http://dx.doi.org/10.1080/00043079.1920.11409675

曲 Published online: 22 Dec 2015.

Submit your article to this journal

Q View related articles $\llbracket$ 
in Philadelphia is dated $1731-44$ but p. 566 the date is 1727-44. Several other such small slips might be pointed out. It is impossible to cover so enormous a field without minor errors, and this book is unusually practical and accurate.

David M. Robinson.

A Hanobook of Greek Vase Painting. By Mary A. B. Herford. Octavo. Pp. xxii, 125. 21 figs. 11 plates. Manchester University Press, and Longmans, Green \& Co., New York, 1919, $\$ 3.75$.

THERE has long been a need for a short history of 1 Greek vases, such as Buschor's good little book in German. Walters' two volumes are too long and contain much that is irrelevant, and other books are devoted to special fields. Miss Herford's excellent, though expensive, book tries to fill this need and does so in many respects. It is, however, hardly a useful handbook of the subject for the beginner or non-specialist for whom it is written. Many will still turn for a brief treatment to the valuable survey of the whole field by the late Professor J. R. Wheeler in FowlerWheeler's Handbook of Greek Archaeology. Nearly as many pages are there given to the subject. The arrangement of the material is better and emphasis is laid by Professor Wheeler on the historical and artistic side which is rather neglected by Miss Herford. Miss Herford's book is valuable because it is the first general handbook to take account of Beazley's countless attributions of vases to new artists, because of several new and unusual illustrations, and because it gives prominence to questions of technique. She has not even confined her remarks on technique to part I, which takes up considerably more than one third of the book, and which discusses clearly and well the Greek potter and his craft, vase shapes (with some omissions), the uses of vases, etc. Part II, called the historical part and consisting of four chapters, on the early wares, the black-figure style, the Attic red-figure style and white-ground vases, and vase-painting in Italy under Attic influence, gives one no clear idea of historical or 
artistic development because the treatment is too brief, because there are only a few plates and those crowded with too many illustrations, and because the narrative is frequently broken by technical discussions. This is especially true of chapter VI.

The vase illustrated in the frontispiece is said ( $p$. $\mathrm{XV}$ ) to be in the Forman collection at Boston. It was formerly in the Forman collection and is now at Boston. Such spellings as necropoles (p. 4) and apotropaeic (p. 14) are objectionable. P. 5, pl. 1c, it would be very useful in the case of vases illustrated to refer to the publications, so in this particular case to Furtwängler-Reichhold, Griechische Vasenmalerei, pl. 17, 18, so on pl. 2 to Arch. Zeitung, 1881, pl. 10, 13. P. 10, we hear suddenly of Milesian ware (ef. also pp. $37,40,55$ ) and of proto-Corinthian (pp. 10,41) without any explanation of the terms, and on p. 17 we are told that the ware formerly known as "Rhodian" was perhaps not made at Miletus. P. 27, just as a reference is given for Nolan amphoras to Am. J. Arch. 1917 (it should be 1916), so for the hydria one might be referred to Miss Fölzer's excellent monograph on the hydria. Plate 1 (b) should be 1 (e), and there is no certainty that Euthymides introduced this kind of hydria since Hoppin and others say that this vase is not by Euthymides. P. 37, the cantharus is not limited to black-figure ware and occurs fairly often in red-figure ware and with painted design. $P$. 40, the name of the archon occurs on Panathenaic vases before 367 , and later than 313 (p. 73). I published one (Am. J. Arch. XIV, 1910, pp. 422 f. and XV, 1911, pp. 504f), now in Oxford, with the name of Asteius who was archon in $373 \mathrm{~B}$. C., and from Eretria came a fragment with the name of Polemon (312-11). P. 40, Miss Herford thinks that some of the Graeco-Italian vases were used as decorations for rooms and that the reverse side with its poorer design stood out of sight. But perhaps one side was a copy of a good Greek design and the other a native piece of work. P. 42, among miniature vases used as toys should be mentioned the several miniature Panathenaio vases. In discussing the uses of vases it 
might be useful to state that, even if many of the vases leak or sweat, that would keep the liquid inside cooler, and is no argument against their use. To-day in Greece where there is little ice such porous vases are used to keep water cool. P. 53, there is not so much connection between proto-Corinthian and Corinthianwares as Miss Herford suggests. There is practically no relation and some proto-Corinthian vases are contemporary with the Corinthian ware which did include some beautifully painted vases such as the Amphiaraus crater in Berlin. P. 54, only four lines are given to Melian vases and nothing is said of the many vases with similar designs found on Delos, so many that several scholars prefer the term Delian to Melian. Little attention is given to the important Theran, Chalcidian, "Tyrrhenian," vases. P. 55, it is improbable that the term: Milesian is any more correct than Rhodian, since this ware has been found in very small quantities in the German excavations at Miletus. In fact, once on p. 57 Miss Herford herself uses the term Rhodian. P. 56, why speak here (also p. 59) of Cyrenaic and elsewhere (pl. 2 for example) of Laconian ware for the same vases. P. 57, the Fikellura or Samian ware, as some would call it, has many slender fairly tall amphoras as well as the squat neck-amphoras. A complete specimen has even been found at Corinth, showing that the ware was not limlited to Rhodes, Samos, and Daphnae. It can hardly be Clazomenaean, as Miss Herford suggests. P. 58, how would any reader know what the Northampton vases are? The treatment of Caeretan hydriae is unsatisfactory. The hydria referred to and illustrated on pl. $2 \mathrm{~b}$ as Caeretan is Cyre. naic and so published in Arch. Zeit. 1881, pl. X, and in Perrot, Histoire de l'Art, IX, p. 505. Miss Herford gives no conception of the caricature and burlesque characteristics of the style. P. 62, it is said that the black-figure style was first brought into prominence at Corinth but some of the early Attic or proto-Attic vases such as the Nessus vase in the Metropolitan, not to mention the geometric and Vourva vases, are as early. P. 65, most archaeologists do not consider that 
the Francois vase gives a faithful picture of the Wellhouse at Athens. P. 72, it is not true that all the vases of Nicasthenes have his sign scratched under the foot. P. 82, the Theseus cylix in the Louvre cannot be an echo of Bacchylides as it dates before his time. Cf. Furtwängler-Reichhold, Griechische Vasenmalerei I, pp. 28f. P. 88, the Greek words 'áskros and maurós should be áspros and mâ̂ros. Pp. 87, 90, the famous Akataeon krater is in Boston, not New York. On pl. 8 (a) the illustration of Macron's cotyle in Boston is so poor that the lower half of the scenes is absolutely black. There is no reference to the publication in Furtwängler-Reichhold, pl. 85. On pl. 9 c, read neck-amphora for the impossible Twisted amphora, and on pl. 10c Meletos master for Maenad master. P. 103, it is hardly true that in the fourth century vases from Kertch and the Cyrenaica polychromy carried all before it, since on many specimens the color is only an accessory. Pl. 11, p. 107, the famous Attic Pronomus vase is called Apulian and Median printed for Meidian. P. 108, most scholars follow Patroni in thinking that the Campanian vases have a closer affinity than Lucanian with Attic vases. P. 111, Posidonia is not the Roman but earlier Greek name of Paestum, and p. 112, Rhinton of Taras should be Rhinthon of Tarentum.

Despite such and other small defects and the bad arrangement of material, the book because of its knowledge of Beazley's work and of Greek vases in general, will prove very interesting and useful and suggestive to one who already has an elementary acquaintance with Greek vases.

David M. Robinson. 